\title{
KelambiR's Eco-lexicals in Serdang Malay: An Eco-linguistic Approach
}

\author{
Faridah $^{1}$, T. Silvana Sinar ${ }^{2}$, Aron Meko Mbete $^{3}$, Eddy Setia $^{4}$ \\ ${ }_{1,2,3,4}$ Departement of Linguistics, Postgraduate School, University of Sumatra Utara (Indonesia)
}

\begin{abstract}
This article studies the KelambiR's eco-lexicals(KEL) in Serdang Malay (SM). It focuses on the collection of KEL that contains the stocks of local knowledge in SM. The data are obtained by interviewing, observing and documenting. The method used in this study is qualitative. The eco-lexicals in connection to kelambiR 'coconut' areprimarily examined by using the perspectives of the followings, such as, the interrelationship, diversity, and environment. To analyze the meanings of those lexicals, the researchers use the external referential, semantics, and the anthropolinguistic concept ofcultural meanings. The findings show that the KEL and expressions are regarded as part of SM's natural resources, language, and culture. The old generations know, understand and use such lexicon and its life principles. However, the situation in the past is contrary to the fact that young generations, today, rarely use KEL, and even do they not recognize and/or understand such words.
\end{abstract}

Keywords: Eco-linguistics, eco-lexicals, environment, KEL, and Serdang Malay

\subsection{Background}

\section{Introduction}

Serdang Malay(SM) is the mode of Malay culture in one area or the central culture of Malay in Deli Serdang and Serdang Bedagai Districts in North Sumatra(Indonesia),in which the Malay Sultanate (MS)was ever getting a fame in its time. As a mode and tool of socio-cultural life, SM had ever recorded and became the portrait of natural reality and of the sultanate life which was considered as the central of culture, especially as the formal languange in the sultanate. It is generally known that culture and verbal picture of Malay environment is really recorded symbolically in Malay language. Particularly, the cultural environment of MS as the central range, and the orientation of social life was also kept and recorded in Malay language. Therefore, as a language that functioned to record the spiritual and material treasure of its community and as a language that was ever reached its heydey in Sultanate of Deli Serdang Bedagai, Malay language embodies a variety of cultural treasuresin the society, and natural resources where it is used.

The fact shows that SM is almost left by its speakers (Sinar, 2010:71). Cultural environment changes rapidly. Consequently, the social civilization of SMmeets its great challenge, aspecially in facing the effect of globalization era and the cross-cultural movement, society and environment, and the norm shift. It affects negatively to SM because the use of this language is rarely found in the society and it will not be recognized by young generation. We need to stress that the parameters in eco-linguistics that are used to and applied in analyzing language phenomena are: environment, diversity, interrelation, interaction, and interdependence. The eco-region, the bio and non-bio diversity, interaction, interrelation, and interdependence among communities from many aspects are recorded in the lexical and grammatical treasure of SM.This study identifies and analyzes the forms of KelambiR lexicon and the individual meanings of the language in the environment observed. The meanings that are analyzed in KelambiR lexicon cover the denotative lexical meanings which refer to external reference (Verhaar, 2006:389) directing to particular plants or animals, and cultural meaning which refers to the contextual usage, including the basic forms and derivative forms.

The individuals of the environmental language (Mbete, 2013:5-7) or ecological linguistics, green grammar (Denison, in Fill, 2001:75-76) with their lexical meaning referentially refer to biotic or abiotic, which is semantically are classified into noun or animate and unanimate things, and countables and uncountables. Those are the pictures of knowledge, specification, understanding, and experience representing "the depth, regularity, and continuity", interaction, interrelation, and interdependence of the speakers of SM towardthe KelambiR lexicon where the speakers live. Lexicon usage referring to KelambiR plants which is contextually regarded as cultural meanings is well discussed. The cultural meanings picture the correlation among the diversity of the lexicon and individual unit in the environmental language (in the form of lexicon) and the diversity of biotic and culture (Skutnabb-Kangas and Phillipson, 2001:2-3), either material or non-material. This gives important information about the meanings of lexicon and verbal texts. It should be realized that the treasure of knowledge and local wisdom, specifically related to biotic and non-biotic diversity and the concepts of its preservation was ever recorded in local language (see Skutnabb-Kangas \& Phillipson, 2001:2-6). 
The basic forms of lexicon and generic lexicon and its derivative forms that have special meanings delineate the intimacy of the relationship and the interdependence with particular plants or animals where SM is used. It was found that there are treasures or KelambiR lexicon and its derivatives, either in the form of nominal, verbal or adjective which characterize the SM. However, they are now vanishing because it is seldom used by the young generation. This will erase the local wisdom and the stock of knowledge of KelambiR lexicon itself.

\subsection{Eco-linguistics}

\section{Literature reviews}

The term of ecology was firstly introduced by Ernest Haeckel (1834-1914). Ecology is the study that discusses how living things are able to survive by making relationship among them and with unanimate things in their environment.Eco-linguistics, a science of interdisciplinary, is the umbrella for all research investigating languages which is in the good relationship with ecology as what was ever said by Fiil $(2001: 126)$ in Lindo and Bundsgaard (2000), or with an approach that studies language and its relationship with environment. Three parameters of eco-linguistics that can become our guidance in making research on language and environment are (1) interrelationship, interaction, dan interdependence, (2) particular environment, and (3) diversity in the environment either human beings or other creatures.Everything is changing except the change itself. The shift also happens to language, culture, environment, and of course to the social-ecological environment of the sultanate. From the point view of eco-linguistics, the existence of language and its users are regarded as organism that appears, lives, grows, develops and finally disappears. It is clearly stated by Fill and Muhlhauster in Mbete(2010:5).

Haugen (1972) in Peter (1996:57) says that eco-linguistics is a language interaction with its environment. Crystal (2008:161-162) says that highlighting the language change, linguistic diversity, behavioral role, and language awareness surely exist.Many experts give definitions on language ecology, eco-linguistics or green linguistics in particular context that are related to the range towards the objective of eco-linguistic study. It is clear that eco-linguistics emphasizes its purpose on awareness towards the problems reflected which is ecologically related to language symptoms and to other perspectives.Haugen (1970 in Mbete 2009:11-12) says that there are ten kinds of study in ecology. They are comparative historical linguistics, demographic linguistics, sociolinguistics, dialinguistics, dialectology, filology, prescriptive linguistics, geopolitics, ethnolinguistics, and typology. Traditional pointsof view are relevant to ecocritical discourse analysis (called asco-crytic text)and linguistics ecology(eco-linguistics) (see Fill, 1996, in Wikipedia). Environmental lexicon described in this study is related to eco-linguistics.

Linguistic ecology portrays the knowledge and understanding of natural and social environment in the forms of language codes. The presence of natural and social environments show an interaction and interrelation of the language itself. Sapir states clearly that vocabulary in a language can picture clearly the physical and social environment. A complete vocabulary in certain language is seen as a complex discovery of ideas, interest and position that the community may concern about. It is possible for us to widen them into the characters of physical and cultural environment (Sapir in Fill and Muhlhausler, 2001:14). However, there are dominant languages in the dynamicenvironment, and language changing in its utterance, especially lexicon utterances that bring about the language change (Mbete, 2009). In other words, language change reflects social and cultural change in the environment. This phenomena happens to sultanate lexicon.In the perspective of eco-linguistics, language change reflects the environmental change and vice versa which they finally affect the language use, such as the lines of a poem in Malay (Sinar, 2010:73).

\subsection{Anthropological linguistics}

Franz Boaz is the pioneer of anthropology linguistics with its variants in America. In Europe it is wellknown as ethnolinguistics (Duranti, 1997). In Indonesia, it is called cultural-linugistics (Riana, 2003:8). Basically they share similarity in names (Crystall, 1992:20; Duranti, 2001:1-2). It is only a matter of perspectives. We observe what people do with language regarding to the utterrances produced, the quietness, and the gestures related to the appearance of anthropology linguistic approach (Duranti.2001:9).Other expert who gave contribution to the development of anthropological linguistics is Franz Boas. He gave influences to the concept of language relativity proposed by Sapir and Benyamin L Whorf. According to his concept, language cannot be separated from the fact of socio-cultural society (Oktavianus, 2006:80). Sapir's contribution through Bonvillain (1997:49) is so famous with his idea that vocabulary analysis in certain language is very important to reveal the physical and social environment where the speakers live. The relation between vocabulary in certain language and cultural value is multi-directional.

Malinowski (in Hymes, 1974:4) says that it is able to search, via ethnolinguistics, the forms of linguistics that are affected by cultural, social, mental and psychological aspects, and what the nature of the form and meaning are. Language use in communication is regarded functional to control and/or to affect in action the speakers (Hymes, 1974:4). Culture is the result of human interaction including human interaction to 
their environment. Therefore, culture appears among individuals not only on one individual because culture is the symbol of social dimension. Geertz (1992:12) says that culture is ideal and physical not a hidden entity.

\subsubsection{Hypothesis of Sapir-Whorf}

Before examining Sapir-Whorf hypothesis (SWH), we need to explain Sapir's contribution to the development of linguistics in the 20th century. By recognizing him well, we can get a clear description about his main ideas that is in relevance to his hypothesis. The second part of this study consists of two parts, forexample, linguistic thought and theoretical review of Sapir's hypothesis.

\subsubsection{Theoretical review on Sapir's hypothesis}

Each research on language and culture or language and way of thinking is always related to $\mathrm{SWH}$, as it is seen in the works of Caroll (1990), Hal (2002), Jennedy et.al. (1994), Sampson (1980), and Trudgill (1974). It emphasizes that researchers who work with language and culture should understand the SWH, and show how important HSW is as an explication of the relation between language and culture. Even, SWH is identical with topic of language, way of thinking and culture.SWH implies two versions: extreme version and moderate version. The extreme version describes that our perspective of the reality is totally determined by our own language. This language determination has similarity to Von Humat's perspective. On the other hand, moderate version describes that our perspective of the reality is determined by our first language. It is called language relativity. Both of these versions are all discussed in this study.

\subsubsection{Heritage of Sapir's intellectualism}

The original thought of Sapir in linguistics is not doubtful. Newmeyer (1986:4) says that Sapir's struturalism came earlier than De Saussure's structuralism: the grammatical aspect of Takelma language by Sapir was published in 1911, while the Course of the Linguistic Generale de saussure was published in 1916. Sapir's book on language appeared 12 years earlier than Bloomfield's 1933. Bloomfield focuses more on language structure; therefore, the first half of 20th century in his heydey period was called as The Decades of Phoneme of Morpheme. In contrary, Sapir, who was Boaz's teacher, is deeply learning anthropology linguistics by which many advocates paid attention on it.

Sapir's linguistics does not concentrate on its structure, but it also widens its scope to culture, literature, mythology, and religion. He is a mentalist. His mentalism is clearly seen in his work on Psychologycal Reality of Phoneme (1933-1949). Phonetic representation does not always refer to phonemic representation because it is directly related to the meaning of utterances which has psychological reality in the mind of the speakers. Mentalism is observed more deeply. Sapir says that language structure gives influences towards the speaker's point view about reality.

On language and culture, Sapir (1921:207;218) reminds us that ideological and sociological languages do not always have cause and effect relation between them, although language cannot be separated from culture. He then adds that when we concern with language and literature (1921:221-2), we are shown the meaning of creativity and its limitation; it is caused by the natural condition of language as a medium of communication. When he said "All Grammar Leak" (1921:38),he reminds us again about the complexity of language structure, which results unsuccessful achievement in all language structures. These mean that Sapir's idea on language is relative and humanistic (Newmeyer, 1986:4). If we try to learn deeper on Sapir's thought on language, then we will be brought to the concept of "language relativity," but the concept implicitly shows "scientific relativity". Sapir, in his period, had a step further in his vision. His wide and deep thought in linguistics is intellectual and worth heritagefor those who are interested in learning language in its social-cultural context.

\subsection{Sociolinguistics}

Hudson (1995:1) says that sociolinguistics is a study of language and its relationship to society. From this definition, it can be inferred that the he divides sociolinguistics into the reality of language (the variety of language) and the reality of society (the symptom, nature, and characteristics of the society and culture as a whole.According to Fishman, sociolinguistics is categorized into a science with three basic elements. The first is the perspective improvement in general linguistics that focuses on the internal aspects related to the society. The second perspective tries to widen the concepts of linguistic competence from the native speakers to communicative competence by altering the perspective and abstract validity study into validity study related to social context (who says, with whom they say, what they talk about, how they talk, and in what situation they talk). This is famous with ethnography communication. The third element refers to sociology which is commonly termed as language sociologywhich of course focuses on the language in the society (speech community). These three orientations, indeed, cannot be separated one to another because they are the special concepts in the basic principles of socioligusitcs. The first and the second elements are included in micro sociolinguistics while the third element is set in macro sociolinguistics (Fishman, 1972:2). 
The above perspectives are being the basic elements in developing those sciences by the experts, such as Hymes, et .al. with their formulation: when we talk, when we should not talk, what do we talk, to whom we are talking, in what situation and how we talk (Hymes, 1974: 277). Hymes and Fishman have analyzed and observed the aspects of validity in relation to the native speakers by using qualitative method.Today, trends in sociolinguistics are developed by Labov et.al. Their perspective is an extreme statement: "Language study in speech community is linguistics", then it is also said that "It is quite natural that the basic data for general linguistic form is language that is used by the native speakers in their daily life."

Labov develops secular linguistics. It is a study of linguistics based on the assumption and hypothesis that linguistics should be based on observation and analysis of language diversity (vernacular varieties) that is used by the native speakers in the social context in their daily life. This refers to quantitative sociolinguistics. The pioneer in quantitative analysis in linguistics isWilliam Labov. This view is also followed by other experts in sociolinguistics, such as, Trudgill (1984), Milroy and J. Milroy (1987), David and Sankoff (1979), Holmes (2001), Gal (1979). Research techniques that are modified with other discipline such as sociology, anthropology, and statistics are proposed by Labov.

\subsection{Language change}

Language behavior that changes as the speakers do may trigger the variety of language phenomenon. Firstly, those phenomenon is marked by deviation of the norms of certain language. Labov (1994) himself terms this as language change in progress. From this term, it can be described that the change commonly happens gradually.Labov (1994) and Aitchison (1991) are two linguists who proposes their idea on this language change. According to Labov (1994), to analyze a language change, there are two ways that can be used, for instance, a way to explore the aspects of language that change gradually. It is done by comparing the existing forms with the past forms. And the second is a way to analyze the relationship between the speakers' behavior change and social category. This is a measure to find the relationship between changes of language aspects and internal language changes.

Labov's explication (1994) uncovers how the mechanism of the language change spreads. There are two segments that can be observed by this language change. They are the spreading of language change in relation with the speakers and its internal aspects of the language. The segment that is related to the spreading of language change is divided into two: natural spreading and concious spreading. Natural spreading occurs sistematically and is commonly done by certain community undeliberately. This results a new variation of language. If one community uses the new variation of the language and the community reaches to a certain period in its spreading and then they will be a new convention which is then used by all of members of the community. This condition makes the language change become a marker of the speakers themselves. Labov (1994) called this changes as change from below, in which at certain time the use of new variation adapts other aspects of language.

On the other hand, language change conciously occurs in a concious condition. It means that the members of that community deliberately applies the language that experiences deviation from the principles of the language. This kind of spreading is commonly done by all members of the community with power, high social status and prestige which is then followed by their subbordinates. Internal spreading of the language change is elated to language aspects, such as lexical, morphology, syntax, and phoneme. The actual fact that can be examined is the lexicon diffusion or phoneme diffusion of certain language that is initiated with small change in a gradual way. If the changes happen to some words then there will be a fluctuation of usage between the old form and the new one by the community where the old form will be left by the sepakers and use the new forms. This kind of spreading happens rapidly and these changes happen to many words (Suastra, 2004:8-15).

Aitchison (1991:105-106) describes that the factors that make the language change are internal psycholinguistics and social factors. The first factor is related to language system and to the psychological aspect of the speaker. In this case, the knowledge and the behavior in the dynamics of social-ecology happen especially in the situation of language varieties. While the second factor concerns with external factor of language system. The changing of language behavior by the speakers might trigger the diversity of language phenomena. Firstly, the phenomena is identified by the language diffusion of the standardized forms of the language. Labov (1994) calls this language change in progress which can be described as language change that occurs gradually andthis is identified by small change. With reference to the language change in Indonesia the change is always influenced by two factors, such as, to use Bahasa Indonesia as national language which is considered as the first demand and to learn and use foreign language as the second one (Masyarakat Linguistik Indonesia, Agustus 2013:116). 


\subsection{Data}

\section{Research design}

The data of this research is KEL that is obtained by interviewing some informants, and carrying out observation including books and dictionaries. The data is analysed in some stages as the followings: (i) identifying and classifying the data obtained, (ii) determining the lexicon category, (iii) finding the derivative forms by analyzing the data by using eco-linguistic parameters, (iv) finding the lexical meaning, the external referential meaning, cultural mening and philosophical meaning, and (v) making conclusion.

\section{Discussion}

\subsection{KelambiR lexicon "kelapa nyiur" (Latin: Coco Nucifera)}

From its category, KEL is classified into basic lexicon of nominal and noun category. In semantic field, KEL is considered as nonhuman and animate objects. KelambiR refers palm plant which has deep interrelation and interdependence and has multi functions. It also shows its diversity through its species or sub species, they are,puyu kelambiR, yellow kelambiR (its fruit), and green kelambiR (its leaves). Based on the biological growth, it can be divided into young kelambiR, and old kelambiR. The last classification shows its cultural context which has meaning and function.

As it is understood that kelambiR grows in many areas, or in certain places, along coastal areas (ecoregion) and it has cultural meaning and high economical value. Whenbeing observed carefully the plant of kelambiR, or its physical parts, has culturally special names which are the derivative forms of the kelambiR lexicon. We need to emphasize the profound knowledge and its special relation between the nature or the unique characters of the plant itself (see Sapir, 2001:14-16). All of this are reflecting the social life, aspecially in the traditional ceremony, such as, entering new house, shaping the baby's first hair off, bathing with dimbar before a wedding ceremony, nonformal and economic institution. These traditional ceremonies are based on the kelambiR lexicon. Furthermore, the variety of cultural culinary also enriches the vocabulary of kelambiR lexicon either in the scope of regional or national.

Compared to other kinds of plant, kelambiR shows its deep interrelation and interdependence because some names can be found from the parts of the kelambiR plant. Some of them are: mumbang 'pistill', describing the stages of the growth, and tempurung hard shell of kelambiR' which functions to protect the fruit or the water of the kelambiR. What is interesting to know then is that the word sudu 'spoon for dish' is derived from the tempurung. Thekal is also taken from the hard shell meaning a tool for measurement (half part of the shell).

With reference to the culinary traditional name, the word santan 'coconut milk' can be found from the kelambiR lexicon. It is manually made from the old coconut so that the quality of thesantan will be better and fatty. The basic nominal category which is ecologically non-biotic and in semantic domain is inanimate; this word becomes the richness, and or the vocabulary collections, of SM treasure in which these collections are acceptedin Bahasa Indonesia. The stages of making santan is initiated by the act of kukur ormengukur'to grate the flesh'which is carried out by meramas 'to squeez with ten fingers' several times until the combination of plain water and the flesh is mixed and looks oily. Moreover, the coconut milk can also be modified to produce minyak kelambiR 'coconut cooking-oil.' This cooking-oil can be used as the ingredients in culinary, hair treatment, etc. The term serundeng is made from the grated flesh by frying (gongseng) it without oil for about an hour and such a term, which becomes basic nominal lexicon, adds the numbers of kelambiR lexicals. The taste of serundeng is either salty, spicy, or tasty.

Furthermore, the green part of the kelambiR plant (umbut) is coded by the speakers as a kind of vegetables that might be eaten after and before cooking. It is practiced by the people even in today's time. The word selodang 'the green part of the shell that can be eaten' is also referred to as a kind of vegetables. The ampas 'waste of the coconut's grated flesh' is also possible to be utilized as weft for cattle. Other words that are derived from kelambiR are sula 'a tool to shell the coconut', lidi 'palm-leaf rib' that is used as a broom, and segandeng 'two old coconuts that are tied with their coir'. All of these words are the derivative forms of language from kelambiR. The stem of kelambiR plant also enriches the kelambiR lexicon, such pokok 'stem' that has been the entity of durable and complex--plural nominal with good quality as the material to build house and bridge. It is commonly derived from natural resourse pokok kelambiR 'oldcoconut tree'. The water in green kelambiR was not only to drink, but it is also utilized as a medicine, aspecially for fever and chicken fox deseases. The coir of the old kelambiR fruit (sabut kelambiR) was also used as a tool to brush the teeth, to wash dishes, and as the place or fertilizer for orchid plant.

KelambiR does not only have function to fulfill material and physical needs, but it also implies moral and ideologial message that is stated in its proverb. From the word sabut, this word might be derived into a new word, such as, bungkuk sabut which refers to an old man with bone deseas. Therefore, the old man should walk in bow position. Furthermore, kelambiR is also believed by the speakers that it is able to be used by shaman to avoid the disturbance from supranatural power. However, this practice almost disappears in recent years because of the influence of religions, especially the religion of Islam in SerdangSultanate (North Sumatra). 
The speakers of kelambiR believethat when they are going to build a new house, they should prepare a pair ofsegandeng kelambiR 'a pair of coconuts'which are put on the beam of the top of the house-to-be. This practice is done during the process of the house building. After the workers have finished erecting the house building, there isanother significant ritual which is phylosophically related to a belief that the act is a kind of improvement. The act of the ritual is marked by the owner of the house to plant a pair of kelambiR in a place around the house before they enter and live in the house. The ritual symbolizes a new improvement in the house and it is meant that the member(s) of the family living in the house always face some of the following conditions, such as, having new ways (strategies)/lucks)fora better life,achieving good health for the members of the family, and getting the kindness and the right rule as indicated by the straight stem of the kelambiR plant.The kelambiR is also belived as the root of the family power or strenght of relationship and as the fertility for the family. All of these reflect the strenght of the interrelation and interdependence of the family members aspecially when they need to respect their ancestors. This tradition is still found in several families today and can be considered as local wisdom which has been one of the collections in National Culture.

The symbolism of kelambiR is found during the shaving off the baby's hair at the seventh day after the birth. The parents of the baby would plant green and old kelambiR. Green kelambiR would contain the hair of the baby after the shaving ceremony and it is planted at the lower part of the land; meanwhile, the old kelambiR wouldbe planted at the upper part of the soil. When the old kelambiR grows and bigger and bigger and after some years have a lot of fruits, the parentsof the baby would say: Ialah kelambiR gombak anakku petang 'This is the kelambiR that was planted during the day of my baby's hair shaving off' (Interview with OK Abdul Khalik, 93 years old, 20 April 2013). The kelambiR that has been planted is marked as the day and date of the baby's birth. It was done in the past to remember the age of the baby because there was no writing system in that period.As it is discussed above the symbolism of kelambiRhas produced three key points to note, for example, the interrelation, interaction and interdependence between the speakers and the nature. Another expression which is especially sent to male or female old person and describes his/her good character is also important for us to know, for instance, tue-tue kelambiR, semakin tue semakin berminyak 'as old as coconut, the older contains more oil.' This expression is used by society to describe an old man or woman who does really have good respect in the society because he/she has shown his/her contribution in social life.

There is a traditional lyric of a local poem tells us about a relationship between milk and santanin which the lyric is addressed to a baby under two years old who is crying, or is going to cry. The poem says: Susu lemak manis, santan kelapa mude, adek jangan nangis diupah tanduk kude 'the milk is fat and sweet, the santan of green coconut, younger brother/sister does not cry, later (you) will recieve horse horn.' In the text, there is a plural lexicon describing certain external referential; the lexicon is santan kelape mude. Theexpression implies a young man who is persuading a child to make the child not cry.There are many other expressions with conotative meaning that present the natural resource, language, and culture in Serdang Malay. These expressions are still used and understood by the old speakers. However, the observation shows that the old respondents who still recognize kelambiR are $60(50 \%)$, those who seldom recognize and seldom understand kelambiR are 30 $(25 \%)$, those who recognize but do not use kelambiR are $10(8.33 \%)$, those who do not recognize but they use it are $10(8.33 \%)$, those who do not recognize and do not use kelambiR are $10(8.33 \%)$. However, from the result of some interviews to young people, almost all of them do not recognize and never use kelambiR in their communication. This condition is caused by the cultural change, the language change and environment change. These changes effect their knowledge and understading on kelambiR. However, the interview data find that the young generations who recogniz and do not use such lexicon are $60(50 \%)$, and those who do not recognize and use such lexical are $60(50 \%)$. This condition threats the existence of kelambiR lexicon in the preceding years and such condition also determines today's generation's avoidance to old terms.

\section{Findings}

KelambiR lexicon is the main lexicon in SM if it is compared to other floral lexicon. This is caused by the functions of pokok kelambiR 'coconut tree' that every part of the tree has certain meaning starting from the root up to the top of the tree. The derivative forms of kelambiR lexicon can be seen in the following lists of words which are sometimes difficult to translate them into English; therefore, literal translation is applied. The lexicons are: mumbang'the fallen green coconut', kal'half part of coconut shell', tempurung 'hard shell', sudu'spoon with long handle', senduk'spoon', santan'milk squeezed from coconut', minyak kelambiR 'coconut oil', ampas 'frated coconut waste', serundeng 'relish of grated coconut and spices', akar'roots', umbut'young trunk in the upper position', nyiur'coconut', lidi 'coconut leaf rib', selodang'a space between the coconut and its coconut stem', pelepah'stem of the coconut bunch', kelongkong'young coconut', sabut'coconut fiber', bungkuk sabut, pokok kelambiR'coconut stem', sula 'a pair of coconut', rebab'big drum made from coconut trunk', rebana'small drum', kelambir muda'young/green coconut', aeR kelambiR muda'water of green coconut', kelambiR tua 'old coconut', and tua-tua kelambiR'as old as old coconut'. 


\section{Conclusion}

The forms and the category of kelambiR lexicon can be inferred as: (a) basic nominal lexicon, (b) basic verbal lexicon, and (c) basic adjective lexicon. In semantic field it can be classified as nonhuman and inanimate. The meaning of kelambiR lexicon consists of : (a) lexical meaning, (b) external referential meaning, (c) cultural meaning, and (d) philosophical meaning.

\section{Acknowledgement}

This is part of my doctoral dissertation and recieves some comments from my promotor and copromotors. I am personally glad to thank Muhammad Ali Pawiro for his careful proofreading, as well as his editing, of this article's earlier draft.

\section{References}

[1] T.S. Sinar, Ungkapan verbal etnis Melayu dalam pemeliharaan lingkungan: Malay and Indonesian studies,Proc.1st International seminar on language, literature, and culture in Southeast Asia, Medan, 2010, 71-82.

[2] Verhaar, Pengantar linguistik umum (Yogyakarta:Gajah Mada University Press, 1986).

[3] A.M. Mbete,Penuntun singkat penulisan proposal penelitian ekolinguistik (Denpasar: Vidia, 2013).

[4] K.T. Skutnab and R. Philipson,Language ecology, in J. Verschueren, J.O.Ostman, J. Blommaert and C. Buleaen (Eds.), Handbook of pragmatics (Amsterdam \& Philadelphia: John Benjamin, 2001) 1-18.

[5] M. Peter, Linguistic ecology language ecology and linguistic imperialism in the Pacific Region (London: Routledge,1996).

[6] D. Crystal, A dictionary of lingustics and phonetics, $6^{\text {th }}$ ed. (United Kingdom: Blackwell Publishing, 2008).

[7] A. Fill and P. Muhlhausler (Eds), The ecolinguistic reader in language, ecology and environment (London and New York: Continuum, 2001).

[8] A. Duranti, Linguistic anthrophology (Cambridge: Cambridge University Press, 1997).

[9] I.K. Riana, Linguistik budaya: kedudukan dan ranah pengkajiannya, unpublished article of pidato pengukuhan sebagai guru besar tetap dalam bidang ilmu linguistik in Universitas Udayana (Denpasar: Udayana, 2003).

[10] D. Crystal,A dictionary of language (United Kingdom: Blackwell Publishing 1992).

[11] A. Duranti, Linguistic anthropology (Oxford: Blackwell Publisher, 2001).

[12] Oktavianus, Nilai budaya dalam ungkapan Minangkabau: sebuah kajian dari perspektif Antropologi Linguistik, Journal of Masyarakat Linguistik Indonesia, Tahun ke 4 No 1, 2006, 115-129.

[13] N. Boinvillain, Language, culture and communication: the meaning of messages(New Jersey: Prentice- Hall-Inc.,1997).

[14] D. Hymes,Foundation in sociolinguistics (Philadelphia: University of Pennysylvania,1974).

[15] Sampson, School of linguistics(London: Blackell, 1980).

[16] P. Trudgill, The social diferentiation of English in Norway (Cambridge: Cambridge University Press, 1974).

[17] Newmeyer, The politics of linguistics (Chicago: University of Chicago Press, 1986).

[18] L. Bloomfield, Language (Delhi: Motilal Banarsidas, 1996 Reprint).

[19] E. Sapir, Language: an introduction to study of speech (New York: Harcourt Brace and Company,1921).

[20] R. Hudson,Sosiolinguistik (translation), Rohayah and M. Jamil (Jakarta: Pusat Pembinaan dan Pengembangan Bahasa, 1995).

[21] J.A. Fishman. The sociology of language(Massachussetts:NewDurihoue,1972)

[22] P. Trudgill, Sosiolinguistik: suatu pengantar. (translation)Nik Safiah Karim (Kuala Lumpur: Dewan Bahasa dan Pustaka,1984).

[23] Milroy and J. Milroy, Obseving and analyzing natural language(Oxford:Blackwell,1987).

[24] J. Holmes, An introduction to ociolinguistics (New York: Longman Publishing, 1992).

[25] W. Labov,Principle of linguistic change: social factors, Proc. 7th Kongres Linguistik Nasional, Surakarta, 2007.

[26] I.M. Suastra,Mekanisme penyebaran perubahan bahasa dan faktor-faktor penyebabnya: sebuah kajian Sosiolinguistik,unpublihed article at orasi ilmiah dalam rangka pengenalan jabatan guru besar tetap Univ. Udayana (Denpasar: Univ. Udayana,2004)

[27] B.T. Aitchison, Language change: progress or decay, (Melbourne:Cambridge University,1991).

[28] A. Aminuddin, Budaya inti, sikap bahasa dan pembangunan karakter bangsa, Journal of Masyarakat Linguistik Indonesia, Tahun ke 31, No. 2, 2013, 115-137. 